\title{
LABOUR PRODUCTIVITY IN THE LIQUID BIOFUELS SECTOR IN SELECTED EUROPEAN UNION COUNTRIES
}

\author{
Michał Borychowski, $\mathrm{PhD}^{1}$ \\ Faculty of Economics, Poznań University of Economics and Business
}

\begin{abstract}
The development of the liquid biofuels sector has been dynamic for more than 10 years, but from the very beginning of this process has been accompanied by a number of controversies as the production and use of liquid biofuels have both positive and negative effects. These consequences primary concern socio-economic and environmental areas. The most important economic benefits are connected with production, turnover and employment in the biofuels industry and the development of agriculture through higher demand on agricultural commodities. The aim of the paper was to quantify labour productivity in the liquid biofuels sector in European Union countries. It is hypothesized that highly developed countries (measured by GDP per capita) have higher labour productivity in the liquid biofuels industry than poorer European Union countries. The second hypothesis states that countries with high liquid biofuel production have higher labour productivity than other countries. The period under research covered the years 2009-2015. The data are mainly from Eurostat, EurObserv'ER consortium and World Bank. This research provides the general conclusion that a high level of economic development is not accompanied by high labour productivity (two types) in the liquid biofuels sector (there is no significant positive correlation). The same applies to the relation between biofuel production volume and labour productivity. The research proves that a high level of GDP per capita or the big scale of biofuel production (and use) is not a determinant of high labour productivity in this sector.
\end{abstract}

Keywords: liquid biofuels, production, turnover, job creation, labour productivity in the liquid biofuel sector

JEL codes: Q16, J24

\section{INTRODUCTION AND THEORETICAL BACKGROUND}

The production and use of liquid biofuels play a significant role in the current European Union's energy policy, as demonstrated by the existence of the 2020 climate $\&$ energy package, to some extent dedicated to liquid biofuels (10\% share of biofuels in the overall consumption of transport fuels) (Directive 2009/28/WE). At the same time, the biofuels sector may be a relevant determinant of the development of the agricultural sector, the bioeconomy and the whole economy primarily through job creation, investment and a higher demand of agricultural commodities, which contributes to the development of agriculture and rural areas and an increase in agricultural income. The development of the liquid biofuel sector has been dynamic for more than 10 years, but from the very beginning of this process has been accompanied by a number of controversies

${ }^{1}$ Corresponding author: al. Niepodległości 10, Poznań, Poland, michal.borychowski@ue.poznan.pl, +4861 8543018 
as the production and use of liquid biofuels have both positive and negative effects.

These negative consequences primarily concern environmental (a small actual reduction of $\mathrm{CO}_{2}$ emissions, more agricultural area, water and other resources allocated for biofuel production) and socio-economic areas: (1) a multifarious impact of biofuel production on prices of agricultural raw materials and food (growth) both in a local and global context; (2) an increase in price volatility; (3) an impact on land prices (growth); (4) a negative impact on food security; (5) high production costs of liquid biofuels and possible unprofitability of this production (Abbott, Hurt and Tyner, 2008; Krugman, 2008; Mitchell, 2008; Rosegrant, 2008; Baffes and Haniotis, 2010; Hochman et al., 2011; Rifkin, 2011; Trostle et al., 2011; Abbott, 2013; de Gorter et al., 2013; Gilbert and Mugera, 2014). On the other hand, the crucial positive effects regarding the development of this sector are the following: the most important being its environmental effect - natural environmental protection through lower greenhouse gas emissions in comparison to fossil fuels - however, this depends on which raw materials are used for biofuel production (Directive 2009/28/WE) and socio-economic benefits: (1) agricultural and rural area development through an increasing demand of agricultural raw materials in the liquid biofuel industry; (2) job creation in rural areas and other sectors of the national economy; (3) reduction of fossil fuel dependence and the strengthening of energy safety; (4) possibility of using agricultural raw materials, which were in surplus every year; (5) production of a significant amount of animal feeds and their components and a reduction of their import as a consequence (Gao, Zhao and Wang, 2010; Alexandratos and Bruinsma, 2012; de Gorter and Drabik, 2012; Kretschmer, Bowyer and Buckwell, 2012; World Bank, 2012; Baffes, 2013; Biokraftstoffe, 2014).

Productivity is a measure of the production effect at a given input of a factor (or factors) of production. It is expressed as a ratio. Efficiency (the criterion of efficiency) is of key importance to modern economics. It concerns the management of scarce resources (production factors) and the optimisation of their use for the production of goods and services.
The overall productivity index takes into account three factors (total factor productivity), but productivity can be measured separately for each factor (land, labour and capital productivity). Thanks to the productivity ratio, the phenomena can be presented at different levels: macro, meso and micro (Staniszewski, 2018). In this article, labour productivity in the biofuel sector, i.e. at the meso level, is examined. Investigating labour productivity in the whole economy and sectors or branches is currently a very important research area. For some countries, increasing labour productivity is the only way to achieve economic growth in the long term. Dorward (2013) argues that agricultural labour productivity plays a foundational role within wider economic development processes.

\section{MATERIALS AND METHODS}

Issues concerning the development of the biofuel market are analysed by many authors, especially in a global context. Researchers concentrate on benefits and losses or threats regarding this market and the relationships between the biofuel market and agriculture, economic policy as well as the macroeconomic environment. However, there is a lack of work and research on labour productivity in the liquid biofuels sector. This article is an innovative approach to the economic aspects of the functioning and development of the biofuels market in the European Union, covering certain countries. The article may be an inspiration for further research on biofuel market efficiency in the European Union, selected countries and worldwide. In addition, it may also provide recommendations for energy policy regarding the directions of development of the liquid biofuel sector. For example, it would seem justified to promote the development of this sector in those countries where labour productivity is highest, and thus has development potential. The aim of the paper was to quantify labour productivity (to some extent it can be identified with work efficiency) in the liquid biofuel sector in European Union countries in order to recognize its level and differences and indicate tendencies. The general formula for the labour productivity indicator is: 


$$
\text { Labour productivity }=\frac{\text { output value }(\text { volume })}{\text { labour input use }}
$$

The labour productivity ratio for the liquid biofuel sector was developed in the paper in two ways: (1) as a relation between turnover and employment (measured in thousand euro per one employed person in the biofuel industry); (2) as a relation between liquid biofuel production and employment (measured in ktoe per one employed person in the biofuel industry):

$$
\begin{gathered}
\text { Labour productivity } 1=\frac{\text { Turnover }}{\text { Employment }} \\
\text { Labour productivity } 2=\frac{\text { Biofuels production }}{\text { Employment }}
\end{gathered}
$$

It is hypothesized that highly developed countries (measured by GDP per capita) have higher labour productivity in the liquid biofuel industry than poorer European Union countries. High GDP often is a result of high productivity of production factors, including land, labour and capital (and technology), thus, in the paper, it was assumed that countries with a high GDP should be more productive/effective in such an area as the biofuel industry, which is technologically quite advanced. The second hypothesis states that the countries with high liquid biofuel production have higher labour productivity than other countries. Countries develop an industry - for example - the biofuel industry because they are effective in this area. Thus, they produce more and more biofuels because of high productivity and - as a result - the economy of this country benefits from that. The period under research covered the years 2009-2015, which results from the availability of detailed data for the liquid biofuel sector in the European Union. Some countries were excluded from the research - these are countries in which the liquid biofuel sector does not play an important role and the share of liquid biofuels in fuels used in transport is low. These countries are: Croatia,
Cyprus, Estonia, Ireland, Latvia, Luxembourg, Malta and Slovenia. All other countries were analysed in the paper, as well as the European Union as a whole. The additional groups considered in the article are the EU-13 (old member states excluding Ireland and Luxembourg) and the EU-7 (selected new member states: Bulgaria, the Czech Republic, Hungary, Lithuania, Poland, Romania and Slovakia. The data are mainly from Eurostat, the European Commission (production of liquid biofuels, share of biofuels in transport fuels), the EurObserv'ER consortium ${ }^{2}$ (employment, turnover) and World Bank (GDP per capita). Some methodological remarks (concerning data) are as follows: (1) job figures are rounded to 50 jobs and turnover indicators to EUR 5 million; (2) employment data refers to gross employment, i.e. not taking into account job losses in other industrial sectors or due to reduced investment in other sectors; (3) employment and turnover refer to the main economic investment activities in the renewable energy technology supply chains, namely manufacturing, distribution and installation of equipment, plant operation and maintenance.

\section{RESULTS AND DISCUSSION}

In 2009, the production of liquid biofuels in the European Union reached 10.5 Mtoe (millions of tonnes of oil equivalent), with the largest share of the following countries: Germany $28.5 \%$ (3 Mtoe), France $22 \%$ (2.3 Mtoe) and further on: Spain 8.4\% (0.89 Mtoe) and Italy 7.7\% (0.81 Mtoe) - Table 1 . The two largest countries therefore produced more than half of the liquid biofuel production in the European Union as a whole. In 2015, the structure changed somewhat as a result of the dynamic growth of production in some EU countries. Despite this, Germany and France remained leaders in the sector, producing respectively: Germany - share of $24.3 \%$ (3.3 Mtoe) and France $-18.4 \%$ (2.5 Mtoe), though their total share fell to $42.7 \%$, which indicates an interest in

\footnotetext{
${ }^{2}$ The EurObserv'ER consortium groups together Observ'ER (France), the Energy Research Centre of the Netherlands, Renewables Academy AG (Germany), Frankfurt School of Finance and Management (Germany), Fraunhofer Institute for Systems and Innovation Research (Germany) and Statistics Netherlands, see: The state of renewable energies in Europe.
} 
biofuels in other member states and their recognition of benefits associated with the development of the industry. Further large producers are the Netherlands $10.5 \%$ (1.4 Mtoe), Spain 9\% (1.24 Mtoe) and Poland $6.9 \%$ (0.94 Mtoe). Within 6 years (between 2009 and 2015), the Netherlands has achieved the highest production growth rate: almost $400 \%$ and Bulgaria: over $430 \%$, however the nominal production level in Bulgaria is still relatively low. On the other hand, in some countries, production decreased in 2015-2009, e.g. in Denmark (from 116 to 13 ktoe, almost 90\%) and Sweden (from 557 to 276 ktoe, by about half).

Table 1 also shows the share of liquid biofuel use in total transport fuel consumption of each country. In this situation, the highest production of biofuels does not necessarily correspond with the highest share. Thus, in 2015, the highest share was held in Sweden (13.8\%) with consumption of biofuels at a level of over 1,000 ktoe and production of $276 \mathrm{ktoe}$, which meant that the country was a significant net importer of biofuels. Also, Austria remained a net importer, with a share of $8.3 \%$ and consumption of biofuels of 645 ktoe in the production of 445 ktoe. In Finland, the share of $11.8 \%$ was achieved with the consumption of $497 \mathrm{ktoe}$ (and similar production, i.e. $472 \mathrm{ktoe}$ ) and in Slovakia a share of $7.5 \%$ with consumption and production less than $150 \mathrm{ktoe}$. The lowest shares were recorded in Great Britain, i.e. 1.8\% with consumption close to 930 ktoe and production 300 ktoe, which meant that demand had to be covered by imports, and in Greece, where the share exceeded $2.2 \%$ with consumption and production at a level of 140 ktoe. The largest producers of liquid biofuels in the European Union recorded mostly low (or average) shares: Poland: 4.9\%, Germany: 4.3\%, Spain: 3\%, the Netherlands: $2.2 \%$, however, all these countries produced much more biofuel than they used to, and it is the level of share that depends on consumption. In France, the share was $6.4 \%$, with consumption of 2.9 Mtoe and production of 2.5 Mtoe.

In 2015, the highest turnover and employment are, of course, in the countries with the highest biofuel production or use - France: over EUR 3 billion and 22 thousand people; Germany: EUR 2.5 billion and almost 23 thousand employed; Italy: EUR 1.1 billion and 6,000 people, Sweden: EUR 1 billion and
4.5 thousand employed. Relatively high employment was observed in Belgium, in 2015 (7,500 people), at a relatively low turnover - only EUR 250 million and in Poland (6,000 employed) at a relatively high turnover - EUR 710 million. On the other hand, the smallest liquid biofuel markets in the European Union considering turnover and employment were: Bulgaria: EUR 50 million and 500 employed, Lithuania: EUR 65 million and 300 people. In the European Union, in 2015, treated as a whole economy, the production of liquid biofuels exceeded 13.6 Mtoe, consumption was close to 14 Mtoe and this sector employed 96 thousand people and generated a turnover EUR exceeding 13 billion. The study also presents EU-13 and EU-7 aggregates. The selected old member states (EU-13) produced a total of 11.5 Mtoe of liquid biofuels in 2015, achieving a turnover of EUR 11 billion and providing over 83 thousand jobs. In turn, selected new member states (EU-7) produced 2 Mtoe biofuels, and the sector reached a turnover of EUR 1.7 billion and employment at a level of over 10 thousand people.

Table 1 also contains data on labour productivity in two presented variants in selected years: 2009, 2012, 2015. The first type was labour productivity in EUR thousands of per one employee in the liquid biofuel sector. In 2009, highly developed countries (these are EU-13 countries to a large extent) achieved both very high productivity values - Sweden (300), Denmark (176), Italy (152.3) and France (126.6) - and low (or very low) productivity values - Belgium (9.6), the Netherlands (43.5) and Austria (48.8). Meanwhile, the new member states reached values ranging from 37.2 (Slovakia) to 120 (Bulgaria). Although this productivity was characterised by high volatility in the period 2009-2015, most countries achieved an improvement. Exceptions were Bulgaria and Sweden (productivity decline in 2015 versus 2009). On the other hand, only a low improvement was noted in a few wealthy countries - Denmark, Finland, France and Italy. The biggest improvements were observed in Hungary, Austria, Slovakia and the Czech Republic. As a result, in 2015 Austria (333.3), Hungary (307.7), Slovakia (236.4) and the Czech Republic (235.7) had the highest productivity, as well as Romania (307.7) and Lithuania (216.7). An interesting 


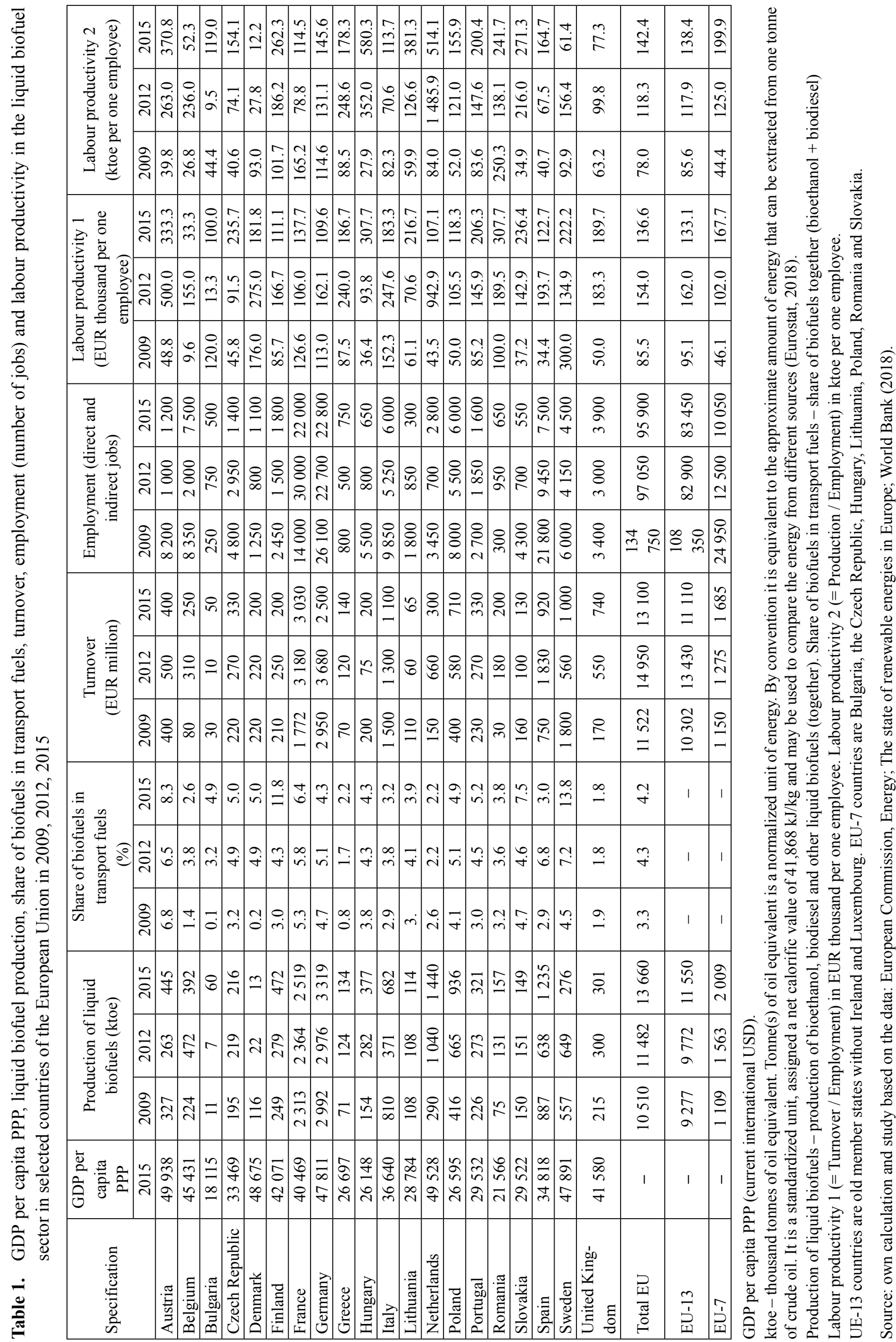


phenomenon can also be observed - in 2015, the EU-7 countries achieved higher productivity (EUR 167.7 thousand per one employee) than in the EU-13 countries (133.1), although in the first analysed year it was the opposite. The new member states (EU-7) had a much higher productivity growth rate - by an average of $45 \%$ per year taking into account the geometric mean compared to $10 \%$ in the old countries. Productivity in thousands of euros per person employed in the biofuel sector in the European Union increased fairly evenly - by around $14 \%$ per year, from 85.5 in 2009 to 136.6 in 2015 . In 2015, the already mentioned largest producers of liquid biofuels in the European Union had productivity in the range of EUR 107-137 thousand per one employee in the liquid biofuel sector. In terms of this type of productivity, Austria was as much as 10 times better than Belgium.

The second type of labour productivity was expressed in ktoe (thousand tonnes of oil equivalent) per one employee in the liquid biofuel sector. In 2009, highly developed countries (EU-13) achieved both high productivity values - France (165.2), Germany (114.6) and Finland (101.7) - and low productivity values - Belgium (26.8), Austria (39.8) and Spain (40.7). Meanwhile, the new member states reached values ranging from 27.9 (Hungary) to 59.9 (Lithuania). Romania is an exception with productivity over 250 ktoe per one employed person in the liquid biofuel sector. Although this productivity was characterised by high volatility in the period 2009 2015, most countries achieved an improvement. Exceptions were Denmark, Sweden and France (productivity decrease in 2015 versus 2009). On the other hand, only a low improvement was noted in a few wealthy countries - Germany, Italy and the United Kingdom. The biggest improvements were observed in Hungary, Austria, Slovakia and Lithuania. As a result, in 2015 Hungary (580.3), Lithuania (381.3), Austria (370.8) and Slovakia (271.3) had the highest productivity, as well as the Netherlands (514.1) and Finland (262.3). An interesting phenomenon can also be observed also concerning this type of productivity - in 2015, EU-7 countries achieved higher productivity (200 ktoe per one employee) than EU-13 countries (138.4), although in the first analysed year it was the opposite. The new member states (EU-7) had a much higher productivity growth rate - by an average of $54 \%$ per year taking into account the geometric mean in comparison to $15 \%$ in the old member states. Productivity in ktoe per person employed in the biofuel sector in the European Union increased gradually - by around $19 \%$ per year, from 78 in 2009 to 142.4 in 2015. In 2015 , the largest producers of liquid biofuels in the European Union had productivity in the range of 114.5-164.7 (France, Germany, Poland, Spain) and the Netherlands: 514.1 ktoe per one employee in the liquid biofuel sector. In terms of such productivity, Hungary (580.3) was almost 50 times better than Denmark (12.2 ktoe per one employee).

Research carried out in this article provides the general conclusion that a high level of economic development (measured by GDP per capita PPP) is not accompanied by high labour productivity (two variants) in the liquid biofuel sector (no significant correlation). The same applies to the relation between biofuel production volume and labour productivity (Table 2). Both hypotheses were rejected. There are only a few highly developed and rich countries with a high labour productivity type 1 (EUR thousand per 1 employed) - Austria and Sweden and with high labour productivity type 2 (in ktoe per 1 employed) - Austria, the Netherlands and Finland, but at the same time there are many highly developed countries with low or very low productivity in the liquid biofuel sector - Denmark, Germany, Belgium and Finland (labour productivity type 1) and Denmark, Sweden, Belgium, the United Kingdom, France and Italy (labour productivity type 2). On the other hand, there are poorer European Union countries (with lower GDP per capita) - mostly new member states (EU-7), which achieved high labour productivity values in the liquid biofuel sector. Romania, Hungary and Slovakia (labour productivity type 1) and Hungary, Lithuania and Slovakia (labour productivity type 2) deserve a special mention. Concerning the second hypothesis - most EU biofuel production leaders have low labour productivity type 1 (Germany, France, the Netherlands, Spain, Poland, Italy and Finland) and low productivity type 2 (Germany, France and Italy). On the other hand, countries 
with lower biofuel production achieve higher labour productivity type 1 - Romania, Slovakia, the Czech Republic, Sweden, Lithuania and labour productivity type 2 - Lithuania, Slovakia and Romania. The study proves that a high GDP per capita level or a big scale of biofuel production (and use) is not a determinant of high labour productivity in this sector. Ac- cording to Dorward (2013) there are some important determinants of higher labour productivity in agricultural, industrial and service sectors. These are: energy, materials, capital, technology, knowledge and institutions. We can conclude that these factors and elements are better and stronger mainly in highly developed countries and these countries should have

Table 2. Rankings in GDP per capita, liquid biofuel production and labour productivity in the liquid biofuel sector in selected countries of the European Union in 2015

\begin{tabular}{|c|c|c|c|c|}
\hline Specification & GDP per capita PPP & $\begin{array}{l}\text { Production of liquid } \\
\text { biofuels }\end{array}$ & Labour productivity 1 & Labour productivity 2 \\
\hline Austria & 1 & 8 & 1 & 4 \\
\hline Belgium & 6 & 9 & 20 & 19 \\
\hline Bulgaria & 20 & 19 & 19 & 14 \\
\hline Czech Republic & 12 & 14 & 5 & 12 \\
\hline Denmark & 3 & 20 & 12 & 20 \\
\hline Finland & 7 & 7 & 16 & 6 \\
\hline France & 9 & 2 & 13 & 15 \\
\hline Germany & 5 & 1 & 17 & 13 \\
\hline Greece & 16 & 17 & 10 & 9 \\
\hline Hungary & 18 & 10 & 3 & 1 \\
\hline Italy & 10 & 6 & 11 & 16 \\
\hline Lithuania & 15 & 18 & 7 & 3 \\
\hline Netherlands & 2 & 3 & 18 & 2 \\
\hline Poland & 17 & 5 & 15 & 11 \\
\hline Portugal & 13 & 11 & 8 & 8 \\
\hline Romania & 19 & 15 & 2 & 7 \\
\hline Slovakia & 14 & 16 & 4 & 5 \\
\hline Spain & 11 & 4 & 14 & 10 \\
\hline Sweden & 4 & 13 & 6 & 18 \\
\hline United Kingdom & 8 & 12 & 9 & 17 \\
\hline
\end{tabular}

1 - the best country, 20 - the worst.

The following data was used to make rankings: GDP per capita - Gross Domestic Product per capita, based on purchasing power parity (PPP), current prices (USD); Production of liquid biofuels - production of bioethanol, biodiesel and other liquid biofuels (together); Labour productivity 1 (= Turnover / Employment) in EUR thousand euro per one employee; Labour productivity 2 (= Production / Employment) in ktoe per one employee.

Source: own study based on data from Table 1 . 
higher productivity in the biofuel industry as well. The conducted research denies the existence of such a relationship.

Furthermore, this research may also provide recommendations for energy policy regarding the directions of development of the liquid biofuel sector. Based on the results from the paper, it seems justified to promote and support the development of this sector in countries where the highest labour productivity exists, and thus, the highest development potential. As Montalbano and Nenci (2018) point out, energy saving policy priorities need to take into account changes (increases) in productivity. What is more, the search for higher energy efficiency (which is one of the goals under the climate and energy policy of the European Union) leads to an improvement in productivity. Such a conclusion could be supported by the theory of comparative advantages (David Ricardo). Taking into account specialisation - the countries with the highest labour productivity could focus on biofuel production, however there are more important conditions to be fulfilled (the supply of agricultural raw materials, no competition for commodities between biofuels and food and feed production as well as positive environmental effects). This specialisation could be even more important in the context of common goals in the climate and energy policy. Some purposes are overnational and formulated for the European Union as a whole.

\section{CONCLUSIONS}

This article is an innovative approach to the economic aspects of the development of the biofuel market in the European Union and may serve as inspiration for further research on biofuel market efficiency in the European Union, selected countries and worldwide. This research provides the general conclusion that a high level of economic development is not accompanied by high labour productivity (two types) in the liquid biofuel sector (no significant positive correlation). The same applies to the relation between biofuel production volume and labour productivity. The research proves that a high level of GDP per capita or the big scale of biofuel production (and use) is not a determinant of high labour productivity in this sector.
Some policy recommendations can be formulated: to support liquid biofuel production in countries where labour productivity is high, to adopt the climate and energy policy to broader circumstances and to treat its goals (concerning the share of use of biofuels in the transport fuels) overnationally.

\section{REFERENCES}

1. Abbott, P.C. (2013). Biofuels, Binding, Constraints and Agricultural Commodity Price Volatility. NBER Working Paper Series, Working Paper 18873, National Bureau of Economic Research, Cambridge.

2. Abbott, P.C., Hurt, C., Tyner, W.E. (2008). What's Driving Food Prices? Farm Foundation Issue Report, Oak Brook, IL.

3. Alexandratos, N., Bruinsma, J. (2012). World agriculture towards 2030/2050: the 2012 revision. ESA Working Paper 12-03, Agricultural Development Economics Division, Food and Agriculture Organization of the United Nations, Rome.

4. Baffes, J. (2013). A framework for analyzing the interplay among food, fuels and biofuels. Global Food Security, 2 (2), pp. 110-116.

5. Baffes, J., Haniotis, T. (2010). Placing the 2006/08 Commodity Price Boom into Perspective. The World Bank, Development Prospects Group, Policy Research Working Paper 5371, Washington.

6. Biokraftstoffe (2014). Bioenergie. Fachagentur Nachwachsende Rohstoffe e.V. (FNR), Gülzow.

7. Directive 2009/28/EC of the European Parliament and of the Council of 23 April 2009 on the promotion of the use of energy from renewable sources and amending and subsequently repealing Directives 2001/77/EC and 2003/30/EC. OJ L 140/16 of 05.06.2009.

8. Dorward, A. (2013). Agricultural labour productivity, food prices and sustainable development impacts and indicators. Food Policy, 39, pp. 40-50.

9. European Commission (2017). Energy, Data \& Analysis - By country, Country datasheets - August 2017 update. Retrieved from: https://ec.europa.eu/energy/en/ data-analysis/country [Accessed 31.10.2017].

10. Eurostat (2018). Glossary: Tonnes of oil equivalent (toe). Retrieved from: http://ec.europa.eu/eurostat/statistics-explained/index.php/Glossary:Tonnes_of_oil_ equivalent_(toe) [Accessed 31.10.2017].

11. Gao, F., Zhao, L., Wang, X. (2010). The Research Review about the effect of biofuel development on agricultural market and agriculture. Agriculture and Agricultural Science Procedia, 1, pp. 488-494. 
12. Gilbert, C.L., Mugera, H.K. (2014). Food Commodity Prices Volatility: The Role of Biofuels. Natural Resources, 5 (5), pp. 200-212.

13. de Gorter, H., Drabik, D. (2012). The effect of biofuel policies on food grain commodity prices. Biofuels, 3 (1), pp. 21-24.

14. de Gorter, H., Drabik, D., Just, D.R., Kliauga, E.M. (2013). The impact of OECD biofuels policies on developing countries. Agricultural Economics, 44, pp. 477-486.

15. Hochman, G., Rajagopal, D., Timilsina, G., Zilberman, D. (2011). The Role of Inventory Adjustments in Quantifying Factors Causing Food Price Inflation. The World Bank, Development Research Group, Environment and Energy Team, Policy Research Working Paper 5744, Washington.

16. Kretschmer, B., Bowyer, C., Buckwell, A. (2012). EU Biofuel Use and Agricultural Commodity Prices: A Review of the Evidence Base. Report prepared for Action Aid, Institute for European Environmental Policy, London.

17. Krugman, P. (2008). Grains Gone Wild. Op-Ed Columnist, New York Times of 07.04.2008.

18. Mitchell, D. (2008). A Note on Rising Food Prices. The World Bank, Development Prospects Group, Policy Research Working Paper 4682, Washington.

19. Montalbano, P., Nenci, S. (in press). Energy efficiency, productivity and exporting: Firm-level evidence in Lat- in America, Energy Economics. https://doi.org/10.1016/ j.eneco.2018.03.033

20. Rifkin, J. (2011). Third Industrial Revolution: How Lateral Power Is Transforming Energy, the Economy, and the World. Palgrave Macmillan in the United States - a division of St. Martin's Press LLC.

21. Rosegrant, M.W. (2008). Biofuels and Grain Prices: Impacts and Policy Responses, International Food Policy Research Institute, Washington.

22. Staniszewski, J. (2018). Impact of the production structures on agriculture sustainable intensification in the European Union Member States after 2004 [PhD thesis]. University of Economics and Business, Poznań.

23. EurObserv'ER (2016). The state of renewable energies in Europe. 16th EurObserv'ER Report (and earlier reports: 2011-2015). Retrieved from: https://www.eurobserv-er.org/category/all-annual-overview-barometers [Accessed 31.10.2017].

24. Trostle, R., Marti, D., Rosen, S., Westcott, P. (2011). Why Have Food Commodity Prices Risen Again? A Report from the Economic Research Service. United States Department of Agriculture, Washington.

25. World Bank (2012). Responding to together and more volatile world food prices, Economic and Sector Work. Report 68420 GLB, Washington.

26. World Bank (2018). GDP per capita, PPP (current international \$). Retrieved: https://data.worldbank.org/indicator/NY.GDP.PCAP.PP.CD [Accessed 28.05.2018]. 